\title{
Jean-Yves Tadié, La poésie de Mallarmé
}

\section{Ida Merello}

\section{(2) OpenEdition}

\section{Journals}

\section{Edizione digitale}

URL: https://journals.openedition.org/studifrancesi/26671

DOI: 10.4000/studifrancesi.26671

ISSN: 2421-5856

\section{Editore}

Rosenberg \& Sellier

\section{Edizione cartacea}

Data di pubblicazione: 1 avril 2007

Paginazione: 205

ISSN: 0039-2944

\section{Notizia bibliografica digitale}

Ida Merello, «Jean-Yves Tadié, La poésie de Mallarmé», Studi Francesi [Online], 151 (LI | I) | 2007, online dal 30 novembre 2015, consultato il 23 novembre 2021. URL: http://journals.openedition.org/ studifrancesi/26671 ; DOI: https://doi.org/10.4000/studifrancesi.26671

\section{Questo documento è stato generato automaticamente il 23 novembre 2021.}

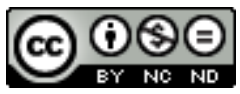

Studi Francesi è distribuita con Licenza Creative Commons Attribuzione - Non commerciale - Non opere derivate 4.0 Internazionale. 


\title{
Jean-Yves Tadié, La poésie de Mallarmé
}

\author{
Ida Merello
}

\section{NOTIZIA}

JEAN-YVES TADIÉ, La poésie de Mallarmé, in De Proust à Dumas, Paris, Gallimard 2006, pp.138149.

1 Tadié riprende in questo volume la prefazione al libro di Thibaudet (uscito nel $1911 \mathrm{e}$ ripubblicato nel 1938) sulla poesia di Mallarmé, in cui il critico mostrava tutta la sua finezza e la capacità intuitiva, cercando di definire la personalità artistica e poetica di Mallarmé, e raggiungendo risultati significativi prima ancora che successivi lavori documentali fossero venuti a comprovare le sue asserzioni. L'A. ne paragona la genialità critica a quella di Curtius, Spitzer e Auerbach , e ricorda come ciò nonostante Thibaudet abbia ottenuta la prima cattedra in Svezia, prima di approdare definitivamente a Ginevra. Thibaudet ha preso in esame il movimento essenziale della poesia mallarmeana, la sua logica, per poi dedicarsi allo studio delle forme, mostrandosi così precursore della critica stilistica e ricercando la psicologia dello stile. L'A. sottolinea come la perspicacia critica di Thibaudet gli abbia permesso anche di intuire il ruolo fondamentale che Mallarmé avrebbe esercitato nel xx secolo. 